\title{
School Choice, Youth Voice: How Diverse Student Policy Actors Experience High School Choice Policy
}

\author{
Kate L. Phillippo \\ Loyola University Chicago, kphillippo@luc.edu \\ Briellen Griffin \\ Loyola University Chicago \\ Bryan J. Del Dotto \\ Loyola University Chicago \\ David Castro \\ Loyola University Chicago \\ Ekram Nagi

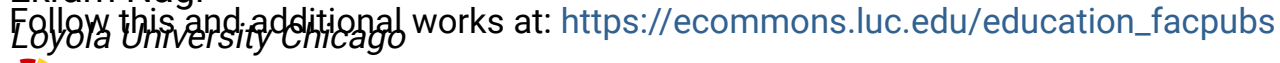 \\ Part of the Education Commons
}

\section{Author Manuscript}

This is a pre-publication author manuscript of the final, published article.

\section{Recommended Citation}

Phillippo, Kate L.; Griffın, Briellen; Del Dotto, Bryan J.; Castro, David; and Nagi, Ekram. School Choice, Youth Voice: How Diverse Student Policy Actors Experience High School Choice Policy. Journal of Educational Policy, , : , 2019. Retrieved from Loyola eCommons, Education: School of Education Faculty Publications and Other Works, http://dx.doi.org/10.1177/0895904819843589

This Article is brought to you for free and open access by the Faculty Publications and Other Works by Department at Loyola eCommons. It has been accepted for inclusion in Education: School of Education Faculty Publications and Other Works by an authorized administrator of Loyola eCommons. For more information, please contact ecommons@luc.edu.

\section{(c) $($ () $\ominus$}

This work is licensed under a Creative Commons Attribution-Noncommercial-No Derivative Works 3.0 License. (c) Sage Journals, 2019. 


\title{
School choice, youth voice: How diverse student policy actors experience high school choice policy
}

\author{
Full citation: \\ Phillippo, K., Griffin, B., DelDotto, J., Castro, D. \& Nagi, E. (2019). School choice, youth voice: \\ Student experiences of high school choice policy. Educational Policy.
}

\begin{abstract}
School choice research is abundant, but rarely incorporates students' experiences or perspectives. This study investigates a diverse group of students' school choice experiences as they applied to, gained admission to and enrolled in high school in Chicago Public Schools, which offers over 130 options. Adapting Ball and colleagues' (2012) concept of policy actor positionality, we analyzed the role of students' developmental and social statuses in students' school choice experiences. Students' policy encounters were developmentally consistent, but their admissions results and subsequent academic trajectories diverged by their socioeconomic status. We discuss these findings' developmental and equity implications for school choice policy.
\end{abstract}

In recent decades, many urban districts have adopted intradistrict school choice policy, ${ }^{1}$ which allows students and their parents to select a preferred public school rather than be assigned to one based on neighborhood attendance boundaries. Proponents argue that school choice can expand students' access to high quality schools, regardless of where they live (Betts \& Loveless, 2005; Burke et al., 2013). Choice advocates laud its potential to boost student performance, since poorly performing schools ostensibly face the threat of declining enrollment and, eventually, closure (Manno, Finn \& Vanourek, 1999). Researchers have investigated whether these claims have been realized, exploring topics such as the distribution of diverse students across schools of choice (e.g., Gold et al., 2010), on-time graduation rates (Lauen, 2009), and district-wide performance changes after school choice policy adoption (e.g., Cordes, 2017; Imberman, 2011).

\footnotetext{
${ }^{1}$ From this point forward, I use the terms "intradistrict school choice policy," "school choice policy," "school choice" and "choice" interchangeably.
} 
School choice stakeholder research centers largely on parents, finding that the choice process is both demanding and important to them, with consequences for their own identity expression (Cucchiara \& Horvat, 2014) and political empowerment (Pattillo, Delale \& Butts, 2014). As such, parents employ available resources like school search consultants, personal time to transport their children, private school tuition and even residential relocation to secure favored schooling options (Kimelberg 2014; Roda, 2015). Limited choice-relevant resources—such as work schedule flexibility, reliable, affordable transportation and housing stability—can constrain lower-income parents' engagement with school choice (Rhodes \& DeLuca 2014; Yettick 2014).

While we know a lot about individual and district-level school choice outcomes and parents' choicemaking experiences, we know far less about how students experience school choice policy. This omission is perplexing, given that school choice policy is arguably for students, and that students most directly carry it out and experience its short- and long-term consequences. The few student-centered studies of school choice (e.g., Sattin-Bajaj, 2014; Stevens, de la Torre \& Johnson, 2011) counter the notion that parents alone drive the school choice process, particularly high school choice. Students in school choice districts must research, apply to, gain admission to and face rejection by schools. They then travel to their schools, and work with those schools' teachers and students. In districts that offer academically selective schools, students must also maintain a performance record consistent with their preferred schools' entrance criteria, and prepare for admissions exams. Young people are policy actors who carry out school choice policy, even though they are often "cast simply as the targets of educational policies" (Conner, Ebby-Rosen \& Brown, 2015, p. 1). To fully understand school choice policy, we must consider these central policy actors' perspectives and actions. 
To do so, we draw upon the concept of policy positionality. Ball, Maguire and Braun (2012) argue that actors' positionality — where they stand in relation to others in their schools and broader society —influences both their enactment of education policy and later policy outcomes. Three types of positionality pertain to students' enactment of school choice. Choice proponents (e.g., DeAngelis \& Erickson, 2018) emphasize students' academic positionality, or how their academic goals, interests and learning styles ostensibly drive choicemaking. Students of different ages engage differently with school choice, so developmental positionality is also pertinent. Parents tend to choose their children's elementary schools, but adolescents are likely to take a more active role with school choice as they gain independence, cognitive sophistication, and a sense of their future goals (Steinberg, 2014). Social status positionality also stands to shape choice enactment. School choice policy's predominantly urban presence means that youth choose high schools in cities shaped by forces such as gentrification, racial resegregation and income inequality (Bader \& Warkentien, 2016; Berube \& Holmes, 2015; Sharkey, 2013). Accordingly, one's social status implies differential individual- and neighborhood-level constraints upon choicemaking. These multiple, intersecting positionalities are critical to our understanding of youth experience of school choice.

The present study—conducted with a racially, socioeconomically and academically diverse group of 36 Chicago Public Schools students—addresses existing gaps in knowledge about school choice policy. We investigated how these students encountered and carried out high school choice policy, from their research about prospective high schools through the midway point of their first year in high school. Our findings reveal that developmental and social status positionalities intertwined to shape participants' experiences. They all found the high school choice process cognitively overwhelming yet meaningful to their evolving academic identities 
and growing autonomy. Yet in spite of these shared experiences, participants' socioeconomic status differences fed into admissions outcome disparities that influenced their subsequent schooling experiences. We argue, therefore, that policy positionality profoundly shapes students' enactment of school choice policy. This study refutes the possibility that all students take up policy in the same way, differentiated only by academic characteristics.

\section{Literature Review: Youth-Centered Research on Intradistrict School Choice}

Youth-centered research on school choice policy represents a tiny slice of the broader body of school choice literature, as we note above. This smaller body of literature tells a consistent story in which school choice appeals to many youth, where available options are stratified, and where individual students' social status and access to capital influence their school choice trajectories. These studies — all of which concern urban high school choice — convey students' widespread desire to choose a school for themselves (Cullen, Jacob \& Levitt, 2005; Gold et al., 2010; Nathanson, Corcoran \& Baker-Smith, 2013; Stevens et al., 2011).

Students' preferences for schools varied by their own current academic performance level. For example, lower-performing students judged schools' quality according to academic themes, location and appeal to their friends and family members, while students in gifted programs valued schools' academic exclusivity, course offerings, and college admissions data (Sattin-Bajaj, 2014). Successful choicemaking bode well: acceptance by a preferred school was associated with later outcomes such as increased academic motivation, attendance and on-time graduation, and, in some studies, elevated standardized test scores (Allensworth, Moore, Sartain \& de la Torre, 2017; Cullen et al., 2005; Lauen, 2009; Hastings, Neilson \& Zimmerman, 2012).

In spite of their drive to choose, however, many students were not admitted to their “chosen" schools. For example, Gold and colleagues (2010) found that fewer than half of 
Philadelphia high school applicants gained admission to their preferred school. Students often cited previous academic performance as a rationale for rejection. "The grades chose it for me," one student explained of his admissions results (Condliffe, Boyd \& DeLuca, 2015, p. 15). Pragmatic factors - such as missed application deadlines or exams, mistakes on applications, difficulties identifying viable schools, and limited preparation for required exams and interviews (Sattin-Bajaj, 2014; Stevens et al., 2011)—also narrowed students' range of choices.

Social relations also shape student choicemaking. Similar to findings from parentcentered school choice research (e.g., Bell, 2009; Holme, 2002), many students learned from their social networks about their school options, and preferred schools already known by family and friends (Condliffe et al., 2015; Sattin-Bajaj, 2014). However, Sattin-Bajaj (2014, p. 75) noted differences in how students" "social spheres" aligned with the tasks of high school choice. Elaborate, information-rich networks helped; sparser networks did not. Network limitations were compounded for families not yet literate in English, when schools did not provide information or guidance about school choice in students' home languages (Sattin-Bajaj, 2014). Parental support, often presumed by school choice policymakers and scholars, ranged from intensive to marginal (Condliffe et al., 2015; Sattin-Bajaj, 2014; Stevens et al., 2011).

Student individual and neighborhood social status shaped choicemaking as well. Lowincome students' involuntary residential mobility was associated with poorer academic performance (Condliffe et al., 2015), resulting in their subsequent difficulty accessing highperforming high schools. Students residing in racially isolated, high-poverty neighborhoods chose schools not just with a generic eye towards safety, as many students did (Gold et al., 2010), but with specific concerns about crossing gang territories or being identified with a rival gang while at school (Condliffe at al., 2015). Students preferred schools near their home, 
regardless of schools' performance (Nathanson et al., 2013; Stevens et al., 2011). Finally, students from nondominant groups are underrepresented in widely preferred schools. Among studies that compare admission rates across demographic groups, all found that Black, Latino, and lower-income students were underrepresented in districts' highest performing, most soughtafter schools (Allensworth et al., 2017; Cullen et al., 2005; Gold et al., 2010). Interestingly, other school choice research involving diverse student groups did not disaggregate individual student data by student race, ethnicity or socioeconomic status (e.g., Nathanson et al., 2013).

The studies paint a picture that is both detailed and riddled with blank spots. Students want to choose their schools, and their choicemaking has a powerful, complex relationship with their social status and access to capital. Still, we have a limited understanding of how these factors shape choicemaking for students with different academic, social and socioeconomic backgrounds. Large data-set studies do not deeply explore student experiences across subgroups. Other qualitative studies present rich data on specific student groups' experiences with choice, such as Condliffe and colleagues' research (2015) with low-income, African-American youth. We still have little evidence of how choicemaking operates across diverse student populations subject to the same intradistrict choice policies. Particularly lacking are data on affluent students' experiences, which could further inform equity considerations. To more fully understand students' choice policy experiences, we must learn about them from diverse groups of students.

\section{Conceptual Framework: Student Positionality Towards Intradistrict Choice Policy}

To better understand youth experiences with school choice policy, we use a conceptual framework that brings the concept of policy actor positionality together with stageenvironmental fit theory. As noted above, Ball, Maguire and Braun (2012) introduce the concept of policy actors' positionality, arguing that actors' relative standing within schools and broader 
society shapes their policy enactment and, in turn, policy outcomes. As an illustration, they note the differences between a novice teacher's and veteran teacher's enactment of the same policy. Organizational seniority and authority, and the nature and extent of professional networks, are but a few individual traits that could shape a teacher's positionality. Applying this notion to students' enactment of intradistrict school choice, we note that their positionality includes, but is not limited to, matters of their academic interests and qualifications. We assumed that students' social status and developmental positionalities would also matter to their policy enactment.

While this article's literature review shows that students' social status positionality—-their socioeconomic status, racial identity and immigration status - influences their school choice experiences, the idea of students' developmental positionality requires further elaboration. Stageenvironment fit (SEF) theory (Eccles et al., 1993; Eccles \& Midgley, 1989; Eccles \& Roeser, 2015) is useful to this end. This theory concerns the fit between 1) schools' organization, environment, instructional practices and curriculum, and 2) students' developmental trajectories, with implications for students' academic motivation, engagement and performance. This perspective encourages consideration of how the match between aspects of schooling — such as academic tracking, instructional models, or building size — and students' developmental needs influences their responses to schooling. For example, Midgley and Feldlaufer (1987) found that junior high students had fewer opportunities to participate in classroom decision making than they had in elementary school, in spite of adolescents' increased drive for autonomy, with negative implications for academic engagement. ${ }^{2}$ SEF theory directs us toward the relationship between school choice policy and the students it targets, creating space to explore the factors that

\footnotetext{
${ }^{2}$ See also Carolan, Weiss \& Matthews, 2015 and Salmela-Aro, Kiuru and Nurmi, 2008 for other SEF theory applications.
} 
inform this relationship. Put another way, SEF theory helps us to investigate students' developmental positionality, an idea which we develop next with choicemaking in mind.

\section{Student policy actors' developmental positionality: Early adolescence}

When students to choose their high schools under choice policy, they typically do so at the age of thirteen or fourteen years. These years fall at the end of early adolescence, generally understood as ages eleven to fourteen. While development at any age is informed by cultural norms, social status, gender, and living conditions (Henrich, Heine, \& Norenzayan, 2010), U.S. youth of this age tend to share developmental characteristics. Four of these particularly pertain to high school choice: cognition, identity development, autonomy, and emphasis on peer opinion.

As young people research and apply to high schools, they must 1) sift through information about numerous schools, 2) consider unfamiliar schools and neighborhoods and 3) organize their responses around application requirements and deadlines. These demands tap early adolescent cognitive capacities. Early adolescent cognition is marked by shifts-typically not complete until later in adolescence - to more abstract, multidimensional and organized thinking (Piaget \& Inhelder, 1973). They experience growth in executive functioning, the ability to problem solve, plan ahead, and coordinate thoughts and behavior. Some aspects of executive functioning do not fully develop until much later (Blakemore \& Choudhury, 2006; Steinberg, 2014). Cognitive development's pacing varies highly across individuals (Keating, 2004).

Early adolescents' emergent cognitive capacities facilitate their identity development, which Roeser and Lau (2002, p. 93) described as a "defining life task" that concerns the discovery of "who one is, who one belongs with, what one is good at, and where one is going in the future." Early adolescent identity development can be a matter of identity affirmation and refinement, or of identity change. While identity remains stable for many individuals throughout 
adolescence, identity exploration and instability are also common during early adolescence (Crocetti, Rubini, Luyckx \& Meeus, 2008). As early adolescents clarify who they are and where they belong, their varied social contexts - among family, peers and community settings - provide rich material from which to draw (Nasir and Saxe, 2003). School choice-driven experiencessuch as the selection of or rejection by preferred schools - function as what Tatum (2017) calls “identity cues." These feed young people's appetite for information to help them define themselves. Identity cues are particularly relevant to the formation of academic identity, or how one sees oneself as a current and future student (Brown, Kanny \& Johnson, 2014).

School choice policy also dovetails with early adolescents' growing autonomy. Selfdetermination theorists Ryan and Deci (2000) assert that when people of all ages can act in accordance with their own motives, they are more engaged in those actions. Volition is especially important to early adolescents, who are accustomed to receiving direction from parents, teachers and other elders but are newly driven to assert independence. Young people's full "endorsement" of their actions is associated with their subsequent positive adjustment to those actions' results, whereas actions that feel forced lead to negative adjustment (Van Petegem, Beyers, Vansteenkiste, \& Soenens, 2012). Student choicemakers face potentially mixed experiences with autonomy. They encounter an opportunity to select schools, suggesting greater investment in, and more positive adjustment to, high school. However, many don't yet have the full ability to choose with true independence, since the capacity for more authentically independent thinking and action tends to emerge later in adolescence (Kegan, 1995).

Peer opinion also matters greatly to early adolescents and resonates with the school choice process. During early adolescence, parent and teacher influence declines while peer influence rises (Lynch \& Cicchetti, 1997), suggesting greater peer influence upon the school 
choice process. Social acceptance is crucial to young adolescents, and they find peer rejection particularly (and even physically) painful (Steinberg, 2014). A successful or failed bid for a preferred school reflects a student's relative status to peers, and so implies potential social triumph or defeat. Early adolescents are deeply engaged in substantial, consequential transitions in how they think, how they see themselves, and how they relate to others around them. These developmental characteristics and needs inevitably shape school choice enactment, reinforcing the importance of understanding students' positionality in relation to school choice policy.

\section{Research Questions}

Our literature review and framework drove our inquiry about a diverse range of students' experiences with high school choice policy. We wondered how students' developmental or social status positionalities might shape their encounters with school choice, and how their experiences with school choice might matter in their lives after admissions decisions were made. We

therefore posed four research questions: 1) How do students experience school choice policy (in this case, high school choice)? 2) How do early adolescents' developmental capacities influence those experiences? 3) How does students' social status influence those experiences? 4) How do students' school choice policy experiences matter for their subsequent schooling?

\section{Study Methodology}

To answer these questions, we used data from a comparative case study (Yin, 2013) of students' experiences with high school admissions in Chicago. Our comparative case study design allowed us to contrast the admissions experiences of student subgroups, such as lowerand higher-income students (as indicated by eligibility for free or reduced-price lunch), students of varying racial and ethnic backgrounds, and students attending different K-8 schools. This study's time frame, in which we followed students from the beginning of eighth-grade into the 
middle of their first year of high school, afforded multiple opportunities to develop rapport with study participants and to learn about their enactment of school choice policy.

\section{Study Sites and Participants}

Chicago Public Schools (CPS) proved an ideal district site for this study. At the time of our study, it allowed all students to choose from a portfolio of over 130 varied public high school options (Menefee-Libey, 2010). Longstanding socioeconomic disparities and racial segregation intertwined with demographic shifts ushered in by the city's burgeoning finance, service and knowledge industries. These forces contributed to resource, achievement and safety disparities across CPS's over 500 K-12 schools (Lipman, 2011). Chicago youth of increasingly unequal social status, therefore, chose their schools within a highly uneven educational landscape.

All CPS students can attend their open-enrollment, neighborhood high school, but $75 \%$ of CPS students typically attend other high schools such as military, magnet, charter, arts, International Baccalaureate (IB), and selective-enrollment high schools (SEHS) (Ali \& Watson, 2017). Competition for SEHS seats is consistently stiff, with nearly 17,000 students applying for 3,000 spots in ten SEHS the year this study's participants began high school (Cox, 2014). CPS changed its SEHS admissions policy in 2009, after the 2007 U.S. Supreme Court ruling (Parents Involved in Community Schools v. Seattle School District 1) that prohibited race-based assignment of students to public schools, and after CPS gained release from court supervision of its desegregation efforts. New SEHS admissions requirements included the use of seventh-grade core course grades, standardized test scores, and high school entrance exam scores as admissions criteria (CPS, 2011, 2013). CPS also stipulated that SEHS admit equal numbers of students from each of four designated socioeconomic tiers for $65 \%$ of open seats. ${ }^{3}$ As a result, SEHS admit

\footnotetext{
${ }^{3}$ CPS used U.S. Census data for individual census tracts to rank each tract, and then divided tracts equally into four socioeconomic tiers. Data used to rank each census tract are: median family income, adult educational attainment,
} 
each tier's highest performing applicants. 30\% of available SEHS spots go to the highest-scoring applicants, regardless of their socioeconomic tier. CPS set aside additional SEHS seats for "principal discretion" admissions, by which rejected applicants could appeal on the basis of individual merit. To test for SEHS admission, students must meet the eligibility criterion, a minimum score at approximately the $40^{\text {th }}$ percentile on seventh-grade standardized tests.

Other CPS schools had a less regimented application process. IB, military, magnet, and career and technical high schools had specific application requirements like open house attendance, interviews or essays. A central CPS office processed high school applications and notified students of admissions results. Students could request assistance from their K-8 school counselor with application submission, but were responsible to submit their own applications.

Within CPS, we purposefully sampled two open-enrollment, neighborhood K-8 schools with similar performance ratings (the highest of three levels used by CPS at the time), comparable public transportation access, and contrasting free- and reduced-price lunch (FRPL) rates (above 90\% and below 40\%). Per our research questions, these criteria were used to hold constant academic performance and transportation, two factors understood to shape choicemaking, while allowing for variation in student SES. We selected Forrester and Vista ${ }^{4}$, which had contrasting student FRPL eligibility rates (94\% vs. 22\%, respectively). Each school's neighborhood had excellent public transportation access to high schools. A nearby elevated train line ran nearly the length of the city, and connected to six other train lines and numerous bus routes. Each school also stood near two express bus routes. Forrester, situated in an unevenly

percentage of single-parent households, percentage of home-ownership, percentage of the population that speaks a language other than English, and a school performance variable calculated from the tract's schools' standardized test scores. CPS identified students' socioeconomic tiers according to the address listed on their high school application. ${ }^{4}$ All school names, and the names of individual participants, are pseudonyms. School information has been slightly modified to further protect participants' privacy. 
gentrifying neighborhood, exceeded CPS's average FRPL rate (85\%), while Vista fell far below it. Both schools' student bodies were atypically racially and socioeconomically diverse among CPS schools, which tend toward demographic homogeneity (see table 1).

From the 67 students who volunteered, we randomly selected 18 students per school (balanced only by gender) to participate in exchange for $\$ 50$ in gift cards, paid incrementally over the study's duration. Our sampling processes produced a socioeconomically, racially, ethnically and academically diverse sample (see table 2). Each school's participants included students who did and did not qualify for FRPL, and who were and were not eligible to take the SEHS entrance exam. Varying intersections of race, SES and ethnicity among participants led to our sample including students of differing socioeconomic status across racial and ethnic groups.

[Insert Tables 1 and 2 here.]

\section{Data}

Interviews with and observations of student participants comprise this study's principal data. Research team members interviewed participants three times: during the application process, after admissions notification by CPS, and during their first year of high school. These semi-structured, individual interviews explored 1) participants' experiences with and reactions to the admissions process, 2) family, school and local resources that they used during the process, and 3) their high school preferences. Interviews took place at participants' choice of a private space at their school or home, or at a public location (e.g., coffee shop). We did not interview parents or caregivers since our research questions focused on student experiences, but did elicit extensive information from students about family involvement in the high school choice process.

The research team also conducted 58 observations of eighth-grade classrooms and high school admissions-related events (e.g. individual and group advising sessions, high school fairs 
hosted by Vista and CPS). Our observation protocol focused on verbal and nonverbal communication related to high school choice, along with evidence of economic and noneconomic resources that seemed pertinent to students' achievement or choicemaking. Data from teacher, administrator and counselor interviews also informed our work. We incorporated information about CPS high schools and the high school choice policy from the CPS website, the hard-copy, 163-page High School Guide (CPS, 2013) which each eighth-grade student received (and could access online), and local print media coverage of CPS high schools.

\section{Data Analysis}

Data analysis began during research team meetings, where members discussed themes emerging from collected data. Students' developmentally-driven experiences of high school choice were not the larger study's original focus, but early on the research team noticed themes consistent with their knowledge about early adolescent development, such as emergent autonomy and cognitive sophistication. Subsequent interviews therefore explored participants' developmental capacities and inclinations through discussion of their experiences with high school applications, and the degree to which peers and parents influenced their choicemaking, their sense of themselves as learners, and their autonomy during the high school choice process.

Research team discussions informed a series of analytic memos (Emerson, Fretz \& Shaw, 2011), along with the development of a code list that combined structural codes derived from the study's design and framework (e.g., developmental and social statuses, rationale for choosing schools) and emergent codes (e.g., academic identity, autonomy) (Saldaña, 2013). For the present study, data analysis and reduction emphasized connections between students' social status and developmental positionalities and their experiences of the high school choice process. This study's time frame allowed us to discuss our findings with participants, which helped us to 
refine our analytic propositions. We compared tentative findings across student subgroups: K-8 school, participant socioeconomic status, racial and ethnic backgrounds, eligibility to test for selective-enrollment high school (SEHS) admissions, and admissions outcomes.

Our positionality as researchers is critical to our findings' validity. Researcher positionality - the researcher's stance in relation to participants with regards to social identity and status (Merriam et al., 2001)—stands to shape a study's focus or results. Acknowledgement of positionality not only keeps us transparent, but can also strengthen our results' soundness. Pillow (2003) contends that scholars must reflect upon how their own and participants' identities shape the research process. Reflection, she claims, can push researchers "toward an unfamiliar, towards the uncomfortable ... not (merely) as clarity, honesty or humility, but as practices of confounding disruptions" (p. 192) that promises to ultimately give way to sound findings.

To meaningfully engage with and interrogate researcher positionalities, this study's principal investigator - a white parent of a school-aged child — convened a racially, ethnically and generationally diverse research team that consisted of seven individuals with differing relationships to CPS schools across Chicago: as alumni, current and previous employees, parents, and partner organization collaborators. She also assembled a review team of senior academics and civic educators very familiar with CPS and contemporary school choice policy. This racially and disciplinarily diverse group - two of whom had children who underwent CPS high school admissions (one the year of our collaboration) — consulted periodically with us on our data collection and analysis process. Both groups openly discussed our procedures and findings in the interest of unearthing "confounding disruptions." These conversations promoted a higher level of integrity with how we interpreted, made sense of, and presented our data.

\section{Findings}


Student participants' developmental and social status positionalities substantially influenced how they understood and carried out high school choice policy. It offered them a welcome opportunity to exercise agency and autonomy over their education, and to define who they were, academically, and where they belonged, leading us to conclude that school choice was developmentally meaningful to them. At the same time, they experienced the choice process as cognitively overwhelming. Even though these experiences were consistent across participant subgroups, the ways in which these experiences affected their admissions results was more varied. Family socioeconomic disparities contributed to admissions disparities across subgroups. Comparatively affluent families activated resources that protected their children from high school choice's downsides, such as rejection by all schools to which they applied. Higher socioeconomic status students—across racial, K-8 school and academic performance subgroups - were disproportionately admitted to their preferred schools. These admissions disparities fueled subsequent disparities in participants' high school experiences of instruction and the school environment, and in their own evolving academic identities.

\section{Students' Experiences of High School Choice: Developmentally Meaningful}

School choice policy was compelling to students beyond the pragmatic matter of finding a school. We consider it developmentally meaningful because it evoked the early adolescent developmental characteristics of increased capacity for autonomy from adults, deep engagement in identity development, and concern about peer opinion and acceptance. Participants liked the autonomy that high school choice offered them. CPS addressed mail to them, not their parents. Students obtained private online application accounts and could apply without their parents' or teachers' approval. About half of participants reported minimal to no guidance from adults at home or at school. "They (parents) just asked me, 'Do you want to go there?"” was a frequent 
comment. Many, but not all, participants who applied independently were immigrants or the children of immigrant parents unfamiliar with U.S. schools, much less with CPS' system and its choice policies. Other students simply felt that they got enough information via the internet, the CPS Guide Book, and from peers and siblings, and so did not seek substantial input from parents or educators. Mr. Menck, the Forrester teacher who offered high school application guidance during lunch and before school, estimated that only about $20 \%$ of the school's eighth-graders sought his assistance. Vista required all students to discuss their applications with the school counselor, but many described the meetings as superfluous, since they had already decided where to apply or had applied even before these required meetings took place. "I already had an idea in the back of my head, so I didn't really need any extra help," Simeon reasoned.

The application process also appealed to students because it empowered them to select (and avoid) schools according to their interests and motivations. Timothy, for example, hoped to be an accountant and so sought schools with AP math courses. Students generally steered away from their assigned, nonselective neighborhood schools. All but one participant (97\%) applied to schools other than their neighborhood school. As another sign of students' motivation to choose, $28 \%$ applied to neighborhood high schools other than their own. Pham applied to three neighborhood schools with similar performance records and entrance requirements, and chose Rey over his neighborhood school. Any chosen school was preferable to an assigned school. "It's a lot better than getting handed to you, like, 'You have to go to this school,"' Joseph explained. The act of choosing a high school—any school—attracted and assuaged eighth-grade students.

High school choice policy not only let students identify with schools; it also identified them with schools. Participants ascribed academic identities to students - those they knew and those they had never even met—-by their school types. They avoided schools with bad 
reputations and sought schools whose students seemed like who they wanted to be (and be seen as). Both students eligible and ineligible to test for SEHS admissions overwhelmingly described SEHS students in more positive terms, calling them, for example, "high standard kids" (Aaron) and "the best students" (Samuél). Two-thirds of all participants called them intelligent, but only two described neighborhood school students as intelligent. Neighborhood school students were tagged far more often with deficit language. $87.5 \%$ of SEHS entrance exam-eligible participants (and one-third of non-eligible participants) spoke of neighborhood school students in disparaging terms such as "lazy" (Anna), "mediocre" (Zhuang) and "dumpster kids" (Joseph). Although new to Chicago, Ina already drew this connection: "It makes you seem not smart to go to Jewell because it's a neighborhood school." Given early adolescents' engagement in identity formation, their imagining of possible future selves (Oyserman, Destin \& Novin, 2015) and their concerns about peer opinion, the prospect of identification with a school mattered profoundly to them.

Public discussion of admission notices—in hallways and classrooms—-further agitated students' developing identities and sensitivity to peer opinion. These experiences proved mortifying for many students, regardless of their admissions results. Forrester compounded this discomfort with a well-meaning assignment that required students to research and present on the high school they would attend. If students had somehow managed to keep their admission results private to that point, they could do so no more. A research team member observed the praise that Janet uncomfortably received when she presented about Thompson, a very exclusive SEHS:

Janet is the only student (from Forrester) that will attend Thompson. Her presentation got a bit of extra attention from Ms. Ainsley and the students (in her class). "Ooooh, Thompson," her peers cooed as she walked to the front of the room to present. Janet seemed to downplay her presentation. It was thorough, but she didn't act proud or 
boastful. Her peers were extremely attentive throughout the presentation. (Field notes excerpt)

Student judgment went both ways. As Christopher approached the podium, one of his peers joked, "He's going to Lawrence," referring to a nearby school that many Forrester students regarded as dangerous and low-performing. Many who heard the comment laughed. While Christopher did not present on Lawrence, de-identified admissions records shared by Forrester showed that one student—possibly sitting in that same classroom, overhearing that commentenrolled there. Students' high schools, both those that accepted them and those they passed over, served as symbolic capital (Bourdieu, 1984) that broadcast an image, however incomplete or inaccurate, of their academic capacity and motivation.

\section{Students' Experiences of High School Choice: Cognitively Overwhelming}

Even though high school applications and admissions held great, even urgent, importance to students, they nonetheless stumbled through the application process. CPS' school choice policies and procedures, which parents and educators also found confusing, aligned particularly poorly with early adolescents' cognitive capacities. High school choice presented participants with overwhelming demands upon their executive functioning and abstract thinking abilities.

Demands for fastidious executive functioning. Long before high school applications came due, CPS held students accountable for their grades and required them to anticipate those grades' consequences. Those who aspired towards selective high schools— such as military academies, SEHS, or IB (International Baccalaureate) programs — had to meet academic eligibility criteria just to apply. Students' seventh-grade standardized test scores, and, for some high schools, their seventh-grade GPA, determined application eligibility and then comprised two-thirds of their high school application portfolio. On one hand, these objective criteria were 
appealingly specific and transparent. On the other, though, they asked too much. As twelve- and thirteen-year-old seventh-graders, many participants did not fully grasp that their academic performance could limit their opportunities later on. They had only a limited capacity to do so, given their still in-process acquisition of executive functioning capacities. Yet, school choice policy demanded that seventh-graders project likely outcomes and plan accordingly.

Participants saw this connection, but often only in retrospect. When asked what they'd advise students entering seventh grade, they focused on what they didn't do: prepare ahead of time. Amani advised that seventh-graders "get some time every week" to study for the high school placement exam, which CPS only administers to eighth-graders. Repeatedly, participants emphasized that decisions students made in seventh grade shaped their future chances. Oliver said he would tell his younger cousin, 'Please don't, just don't flunk this year, like, 'I'll do better the next year.' Because it's not gonna work like that. You can't change what you did in the past."

\section{Demands to navigate highly complex application requirements. The tasks of} researching high schools also strained eighth-graders' cognitive capacities. Printed information about school options demanded extensive abstract thinking of its readers. CPS provided its High School Guide (2013, p. 4) as, in its own words, the "best resource for understanding the application and selection procedures, as well as learning about the wide variety of options available." Yet, this exhaustingly detailed catalogue proved a lot to digest. It gave a full page of information for each of 130 high schools, listing standardized test and ACT scores, graduation and college enrollment rates, school type, enrollment size, academic programs and languages taught, extracurricular activities, public transportation accessibility, school uniform policy, and admissions requirements and procedures. Some information, like testing stanines and attendance boundaries, were unfamiliar to many eighth-graders. Many schools' pages included information 
about multiple within-school programs, each with different application requirements. Students related to the Guide in small, manageable bits. Gerardo sought schools that didn't require uniforms. Ime focused on graduation rates. Given the overwhelming chunk of information on each school's page, students could easily take in its content incorrectly or incompletely.

Most participants (97\%) applied to multiple schools and often multiple school types. To do so demanded substantial organization and planning — in other words, executive functioning. For example, Ina applied to eleven schools. These included: SEHS that required a district-wide entrance exam along with grades and test scores (some of which she lacked as an out-of-state transfer student), performing arts schools that demanded auditions, schools that required essays or interviews, schools that used their own entrance exams, and schools that admitted students by lottery. She had to manage multiple applications' specific requirements, such as eligibility standards, procedures for submitting required materials, procedures for registering for entrance exams, interviews or auditions, and deadlines or set dates for all these. Some, but not all, schools required attendance at open houses for admission.

All these provisions laid out a bewildering menu of tasks that students had to remember, sequence, coordinate and execute. Field notes from Raphael's session with Ms. Richman, Vista's counselor, illustrate the confusion that could follow from these tasks' complexity:

“Have you signed up for the (selective-enrollment entrance) test?" Ms. Richman asked. Raphael said that he "did something" involving selective enrollment and something about Edmunds High School.

Ms. Richman asked if he had done the International Baccalaureate (IB) application for Edmunds online. "I'm not sure, it was before you were allowed to apply," he responded. 
"What schools are you interested in?” Ms. Richman asked.

“Condor Honors, Condor Arts” Raphael replied.

"You can download the PDF application. . . Keep talking to me, Raphael."

"Perry (SEHS), Edmunds' Fine Arts program."

"Good."

“St. Michael’s (private school)," Raphael added.

"Did you sign up for their shadow day?"

"Not yet."

“Okay," Ms. Richman continued. "So you're going to apply to Condor Arts and Edmunds Fine Arts, Condor IB?"

“No, Condor Honors," Raphael corrected her.

"Are you eligible to apply to Condor's IB?"

Raphael nodded yes.

"You might as well apply," Ms. Richman suggested. "If you're comfortable going to those schools you may as well apply to different programs at them." (Condor will require Raphael to submit 3 different applications — both online and paper- to these programs.) Ms. Richman forged ahead. "The Catholic schools, you need to get their applications." She told him that he'll need teacher and counselor recommendations and that he should ask "earlier rather than later." 
... After a pause, she said, "Have you looked at the Fine Arts Academy (public performing arts school) stuff?”

"Not yet."

“Here's the deal: What they really want is an online application. They don't want to sift through paper. It's due earlier: December 6. And you have to do an audition.”

Raphael was one of this study's more organized participants, and had home internet, computer and printer access. Still, he faced a cognitively staggering volume of application requirements.

Applications' burden on students' executive functioning explained in part why most students had minimal direct contact with high schools to which they applied. Thirty-two (89\%) attended at least one high school open house, but most did not visit all the schools to which they applied due to open house conflicts with personal, family or other schools' open house schedules, transportation challenges, or simply not knowing when open houses occurred. CPS advertised open houses on its website, and both Vista and Forrester publicized many as well. In the end, though, $53 \%$ of participants enrolled at a high school they had never visited.

The cognitive demands of the application process - particularly the need to remember so many different requirements and details and act in accordance with them—limited the the number of students' viable application submissions. Many students submitted applications to IB programs but were eliminated (with no chance to correct their mistakes) because they did not attend those programs' mandatory open houses before applying. Additionally, students at times misunderstood application procedures. Michael was dismayed that Osborne, a SEHS, had rejected him even though his test scores exceeded its cutoff score (published online when CPS sent admissions notices). CPS admitted him to Perry, a SEHS that was not his top choice. He and 
his teachers discovered that he had ranked Perry above Osborne on his application, and that CPS admitted him to the school he listed first, rather than the most selective of his listed schools, as Michael incorrectly thought would be the case. He had no opportunity to amend his application and attend Osborne, the school to which he would easily have gained admission had he ranked it first, because its ninth-grade slots were already filled.

Across participant subgroups, the cognitive demand imposed by school choice was more than most students could manage. They weren't developmentally "behind." High school choice simply overwhelmed their current cognitive capacities, and left no margin for error. Participants were developmentally vulnerable to school choice. They approached it with eagerness and even a sense of urgency, but they struggled with it nonetheless. Despite these striking consistencies across participants, eighth-graders who occupied the same classrooms, and even the same advanced math classes, found themselves scattered across CPS's high schools the following year.

\section{Family Socioeconomic Disparities Contributed to Admissions Disparities.}

While developmental vulnerability to school choice policy was consistent across our study's participants, the extent to which that vulnerability affected admissions results was not. Relatively high family socioeconomic status - across racial and academic performance subgroups - was highly associated with admission to preferred schools. Even though most participants preferred to select high schools independently, and some students were truly on their own to research and select schools, more affluent families possessed and activated resources that protected their children from high school choice's various downsides. These resourcesdescribed by student participants - helped usher participants who possessed them into schools of their choice. Students' social status positionality mattered tangibly to their admissions outcomes. 
Higher SES translated into resources that helped students research, select, gain admission to, enroll in and attend schools that they and others perceived as desirable. Paul and his mother had already prepared for him to apply for a principal discretion spot at Thompson (an SEHS with a 4\% acceptance rate) long before Thompson rejected him. They put that contingency plan into motion after Perry (a less exclusive SEHS) admitted him instead. Paul recounted:

We already had the statement letter written up.... We looked on the website to see if they had anything posted yet but they didn't. We figured that we probably had to have some sort of letter to the principal saying like why we should be chosen. The other part was to have a list of your accomplishments from 6th to $8^{\text {th }}$ grades. That wasn't too hard because we have certificates and stuff all in one place.

Paul's use of the term "we" when describing these activities is telling. His mother, employed part time while his father worked a full-time professional job, coordinated these activities for him. Other more affluent participants reported that their parents did the same. Paul's mother brought him to open houses and "shadow" days at two private schools, including one outside of Chicago and unreachable by public transportation. Both schools admitted him. These admissions resulted in part from Paul's mother's research and communication efforts, correcting any missteps he might have taken, as well as her ability and availability to drive him to these school visits. These actions were ultimately successful: Thompson admitted Paul via the principal discretion process. While Paul was indeed accomplished, much of this particular success was his parents'.

Lower-income students' parents demonstrated interest in and concern about their children's high school choices. They did not, however, possess the same repertoire of admissions-boosting resources. Udai, a lower-income student, explained, "We just moved to the United States three years ago, so we don't know a lot of stuff.” He extensively researched 
schools and attended two open houses. By his account, though, his parents offered little specific support. They could not bring him to the open houses, including those at schools that required open house attendance for admission, because of work and child care responsibilities. Udai's parents urged him to select a prestigious public high school and his father was upset when he was rejected ("He still feels that I slacked off"), but they had little tangible help to offer.

Family economic capital also purchased tangible admissions support. Private courses to prepare students for their state standardized tests and the high school entrance exam cost approximately $\$ 400$ each. Only one lower-income participant (of 23 total) enrolled in either course, while two-thirds of more affluent participants did. Some took two courses. The score for each exam comprised one-third of the high school application portfolio. These courses helped with content and familiarized students with the testing format. Cal claimed that he did not learn much new content in his test prep course, but that "it helped with the test taking strategies because you can't use a calculator on the test. It also helps with getting through questions quickly." Marisol, a lower-income, Forrester student, found the entrance exam bewildering: "I did study hard for it, but I didn't exactly get the results I wanted. Sometimes I got a question wrong and their questions on different sections are timed so the time made me rush more." Like every other Forrester participant, Marisol had never even heard of test preparation courses.

Differences in access to protective family capital correlated with categorically distinct admissions results (see table 3). Lower-income students were overrepresented among students who enrolled at schools with moderately selective and nonselective admissions (seventeen of twenty-one total). Relatively affluent students were overrepresented (seven of nine total) among students who enrolled in Chicago's most academically selective and audition-based schools.

[Place table 3 about here.] 
Comparison of racial subgroups was weakened by small cell sizes and a large multi-race subgroup. Comparison of students of color to white students revealed substantial differences only in the number that enrolled in nonselective schools ( $40 \%$ to $9 \%$, respectively). All students of color enrolling in nonselective schools also qualified for free or reduced-price lunch.

\section{Admissions Disparities Fueled Subsequent Academic Disparities.}

Socioeconomic disparities involving high school choice did not stop with participants' acceptance letters. Rather, these disparities carried over into their high school lives. Students admitted to their preferred schools tended to encounter more enriched learning opportunities. $\mathrm{Cal}$, an affluent student admitted to Osborne (an SEHS with a 3.5\% acceptance rate), would have access to over thirty AP courses and a thoroughly college-going (92\%) student body. Marisol, who qualified for free lunch, was rejected by the same school. Her high school would offer only two AP courses and would send one-third fewer students to college, and posted an average ACT score of 19 compared to Osborne's 25. Both students expressed enthusiasm about entering their high schools, but their academic opportunities were simply not the same.

Admissions disparities fed into later academic identity disparities. Disappointed after rejection by all SEHS to which she applied, Davea, a working-class student, recalibrated her academic self-image to her future at a nonselective neighborhood school. She stated that SEHS were for "more advanced kids" and admitted "smarter" students. Isaac's academic identity was boosted by his admission to both an SEHS and a competitive Catholic school: "For the (Catholic school) interview you have to know what you're talking about. And for selective enrollment you have to be very book smart." His parents' social and professional networks, availability to schedule and transport him to public and private school admissions events, and their ability to 
pay high school and test prep course tuition, also informed his certainty about his own smartness and of his belonging at his chosen high school.

Participants' academic identities also included an appraisal of their own work ethic.

Participants generally considered students to deserve the opportunity to attend a "good" school if they put forth enough effort. Akin explained this widely held viewpoint:

If you work hard you probably could go to a good school. But if you don’t work hard you're probably gonna have to go to a school you probably don't want to (attend).

Participants admitted to their preferred schools credited their results to their conscientious labors. Those not admitted to preferred schools also felt that their efforts culminated appropriately. Samuél received no high school acceptances, while Osborne, his top choice, admitted his friend Lee. "It was heartbreaking but I congratulated her," he recalled. When asked why he thought only Lee had gotten in, he answered, "She is smarter than me, put more effort in than I did. She really deserves it." Samuél said he too put effort into his classes, tests, and applications. Yet he felt he had not deserved a spot at Osborne as much as Lee did, insisting, "You can't just get what you want, you have to deserve it." While Osborne and all SEHS admitted as a matter of policy students from a range of income levels, the overrepresentation of higher-income students at participants' preferred schools contributed to participants' conflation of effort with SES.

Participants saw themselves and others as "getting" the high school they deserved. This view fueled an image of more affluent students - whose family resources helped most of them secure their spots - as exceptional, hard-working and meritorious. This response was notable with Jennifer and Aurora, both admitted to the highly competitive Fine Arts Academy (FAA), a public arts school that required an audition for admission. Jennifer, an aspiring musical theater performer, moved with her family to Chicago from a nearby suburb to have the opportunity to 
audition for FAA. She took private, individual voice coaching and began an additional theater class before her audition. These experiences, Jennifer said, "really helped me get prepared for whatever they asked me to do, and they also made my audition not as nerve-wracking." After being admitted, both described themselves as deserving their spots because of their efforts, even though their private, fee-based preparation was something that not all applicants - in a district where $85 \%$ of students qualified for free or reduced-price lunch-could access. "I've worked towards this (FAA) through my whole life, so I'm really determined," Aurora explained. Their capital-aided conclusions about their work ethic were held more broadly. $69 \%$ of more affluent participant, but only $43 \%$ of lower-income participants, saw themselves as hard workers.

Other family investments similarly shielded students' academic identities, leading them to draw positive conclusions, or at least not to feel compelled to think negatively about themselves as students. Timothy, a family "legacy" at a local private school, did not need to apply anywhere likely to reject him due to his admittedly middling grades, and avoided the risk of having to attend a stigmatized high school. When admission letters arrived for classmates, it was "no big deal" in his words. He did not have to report rejection to his peers, process information in public, nor have rejection shape his academic identity. Participants with successful bids could look upon themselves as hard working and consequentially headed to bright futures. That this group of students could count on family capital underscores how much capital could differentially shape academic identities within a school choice policy context.

Participants' admission results also shaped their engagement in high school. Students not admitted to their preferred schools, who were predominantly from lower-income families (10 of 14 total), tended towards lower investment in their high schools. Amani, a student from a middle-class family, readily engaged in her SEHS's extracurriculars, and loved its diversity and 
academic rigor. By contrast, her lower-income eighth-grade classmates generally had fewer energizing experiences. Leah felt disappointed at Edmunds: "I thought they were gonna push me to do better but they're not," she explained. Samuél still thought about Osborne, the SEHS that rejected him. "I would have probably been good if I ended up there," he said. "But Beam (where he enrolled instead) is not a bad option." Some participants attended "not a bad option" schools. Others attended their dream schools. Others felt stuck at schools they actively disliked.

\section{Discussion and Implications}

A diverse group of 36 Chicago youth expanded our understanding of intradistrict school choice policy as they researched, applied to, enrolled in, and attended high schools. We explored whether their developmental and social statuses shaped their enactment of school choice policy. These positionalities did indeed shape their policy enactment, beyond the matters of academic performance or interests that school choice architects emphasize as key drivers of choicemaking, and ultimately contributed to inequitable policy outcomes. Below, we discuss what students' developmental and social status positionalities meant to their school choice enactment, and what these findings suggest for school choice policy moving forward.

\section{Students' Developmental Positionality: At Odds With School Choice Policy}

Students' developmental positionality towards high school choice policy was neither all good nor all bad, but, rather, tense. Scholarship on early adolescence clearly delineates the developmental needs young people are experiencing as they transition into high school. School choice policy_particularly in environments where at least some school options are in insufficient supply—works at odds with those needs. This conflict occurred in three areas: academic identity formation, cognitive capacity, and autonomy. 
As enacted in Chicago, school choice policy unintentionally assigns academic identities to students at a time when they crave "identity cues" (Tatum, 2017) but before they are ready, developmentally, to commit to a conclusive identity. Young adolescents' identity development is characterized by exploration, trial and error. Premature identity resolution may shut down the academic identity formation process before it is complete (Crocetti, 2017). The policy-driven classifications that participants encountered — through application eligibility or ineligibility, admission to or rejection by particular schools, and ultimate enrollment at one high schoolunwittingly identified them using very limited information, possibly cutting them off from other potential identities they might also explore.

Second, cognitive overload surfaced as participants enacted school choice, separating some from learning opportunities they fervently desired. The volume and school-to-school inconsistency of required, time-sensitive school choice tasks proved too much for even the most responsible, resolute eighth graders. This crush of demands brought on confusion and curtailed choice. One might question why high school choice policy's cognitive match is of greater concern than it is when older adolescents—only four years older—undergo a similar competitive college admissions process. This question, though, ultimately reinforces the argument that high school choice is developmentally misaligned with early adolescence. Most students pursuing college admissions have completed adolescent cognitive reorganization. They are more able to coordinate and execute the labyrinthine demands of researching and applying to colleges (Blakemore \& Choudhury, 2006; Paus, 2005). High school choice's current structure, though, runs the risk of landing students in schools not suited for them, not because of academic performance or motivational shortcomings, but because of predictable developmental limits. 
Third, high school choice policy in settings like Chicago, where the demand for highperforming schools is high, challenges early adolescents' drive for independence and autonomy. Student participants admitted widely preferred schools tended to have both strong academic performance records and parents who possessed economic, human and social capital that they "spent" on their children's behalf. It is understandable that parents would act to protect their children amidst such a stressful, potentially defeating, experience. Yet, parent involvement in school choice may bring new problems. Youth may find their dependence on parents prolonged when a late assignment, a lost form, a poor grade or a missed open house could lead to restricted educational options. High-stakes school choice may inflame behavior by some affluent parents who employ so-called "helicopter parenting"-a subject of much recent attention (e.g., Segrin, Givertz, Swaitkowski, \& Montgomery, 2015) and a response among some parents to high-stakes school choice (Cucchiara, 2013; Sattin-Bajaj \& Roda, 2018). Overprotectiveness, perhaps understandable under such circumstances, may work to students' developmental detriment.

\section{Students' Social Status Positionality: Differential Protection, Refracted Results}

We asked what role students' social status positionality would play in their school choice experiences, particularly since existing data painted rich pictures of relatively narrow demographic groups' experiences. Our findings illuminate how social status and parental capital interacted with student choicemaking and subsequent experiences. Capital exerted a powerful influence in tandem with student academic performance. A few affluent participants were rejected by their preferred schools, and a few lower-income students secured spots at their-and everyone else's - dream schools. Overall, though, students with more capital more frequently ended up in their preferred schools. It is worth noting that capital is not entirely synonymous with social status. Neither race nor immigration status had a strong association with admissions 
outcomes. This finding may result from our diverse yet small sample, and so merits caution in interpretation, but nevertheless calls attention to capital's role in choicemaking.

When capital aligned with school choice tasks, it shielded students from unwanted outcomes, pre-emptively positioning them well with regards to their preferred schools' admissions criteria. Recalling Timothy, his family's social networks and income led him to private school, diverting him from rejection by other schools. He chose, but his parents' capital protected and facilitated his choice's fulfillment. Affluent students' protected choicemaking had a refractory quality over time, in which their admissions results gave way to subsequent academic engagement, satisfaction, and optimism. Another refractory process occurred for students — predominantly from lower-income families—whose preferred high schools rejected them. A sense of dejection, disengagement and pessimism about their schooling followed their largely under-protected choicemaking experiences. We find capital's influence upon school choice troubling not only because of its relationship to academic identity later on, but also because this relationship occurs at a time of intensifying inequality in U.S. cities. As disparities pervade urban life in areas such as housing, employment security, earnings and public safety, economic inequality promises to translate into unequal school choice experiences and outcomes.

\section{Policy Implications}

This study highlights that many students' high school choice experiences are neither optimal, equitable, nor what we assume choice architects had in mind. Policymakers possess the potential to use this knowledge to adjust existing high school choice policy, or to modify choice "blueprints" before adopting them anew. Youth participants' perspectives on high school choice imply several adjustments to high school choice formulas, which could help ensure that a 
student's developmentally understandable missteps or limited access to choice-relevant family resources do not translate into potentially damaging missed or denied educational opportunities.

Districts could address student developmental needs by streamlining school guides and application tasks. With more concise information about schools and fewer steps to remember, coordinate and complete, students might find themselves less often left out of suitable schools due to application errors or omissions, or limited adult oversight. Chicago's introduction of a single best-offer system, already in place elsewhere, holds promise. On one centralized website, it lists all schools for which a student is eligible to apply, and informs them about required steps (e.g., open house attendance, entrance exams) for any selected schools. System-generated cues to complete application requirements would address students' need for organizational support. This system requires internet access and readability in students' home languages to be effective, however, and of course stops short of ensuring that students complete required events like interviews or exams. The elimination of such events, or their incorporation into K-8 schools, could further equalize students' access to preferred schools.

Support with entrance exam preparation and admissions guidance could lessen school choice's potential to exacerbate socioeconomic inequality. The market currently offers test preparation courses, which some of this study's participants, who knew of and could afford them, found useful. Policymakers could subsidize course tuition or support test prep company partnerships with community organizations, thereby expanding course access. These approaches would rely upon the private sector to address "public school problems," but might reach more students. Similarly, school districts might adapt these market-style interventions. School counselors could provide entrance exam and admissions guidance as outside companies do. Such efforts are already underway in New York City (Sattin-Bajaj et al, 2016). 
Districts could also adjust admissions formulas for widely-preferred high schools. CPS took a decisive step towards equity in 2009 when it opted to divide $65 \%$ of open seats at SEHS across four designated socioeconomic tiers, something that other urban districts with selective schools (e.g., New York City, Philadelphia) do not do. However, Latinx and African-American students remain underrepresented in cities with and without SES-based admissions criteria for selective schools (Taylor, 2018; Loury, 2017). Remedies could involve an introduction or recalibration of formulas aimed at increasing underrepresented groups' admission rates, although the Supreme Court's 2007 decision to disallow race-based assignment to public schools likely limits such efforts' reach to student SES. Randomized admission of qualified applicants is another option, as is the elimination altogether of high stakes entrance exams.

Another possibility is to change the supply of "preferred" schools. Competition to access preferred schools is intensified by these schools' limited supply. Districts could open new schools that replicate preferred schools, or could strengthen "deselected" schools by expanding course offerings, providing free transportation and improving school climate. Moves like these, of course, would require substantial new spending on public schools, in an era where disparities between schools are sturdy if not increasing, and where neighborhood segregation already constrains school choice (Author, 2017). Many of the measures mentioned above would increase the resource demand upon school districts and would also likely call forth more of the criticism and competitive frenzy that already surround school choice. These factors suggest the potential political unpopularity of measures to equalize educational opportunities on a district-wide basis.

\section{Limitations}

This study's design and sampling decisions resulted in limitations to our findings' generalizability. We carefully selected schools and youth participants to represent the diverse 
variety of urban students who engage with school choice policy, yet these participants cannot help but reflect their particular situation in Chicago, one of many cities to enact school choice. Their racial, ethnic and linguistic backgrounds, as well as their connection to specific neighborhoods and educational and social policies, are not universal among similar American cities. Rather, they emerge from Chicago's unique intersections of migration and settlement patterns and accumulated policies (Cuban, 2010). School choice policy in Chicago has relevance beyond Chicago. But some of its idiosyncratic features, such as the use of socioeconomic tiers to distribute selective-enrollment high school seats, do constrain our findings' generalizability.

This study's student sample also influences our results' generalizability. As students from similarly high-performing, open-enrollment, K-8 schools in neighborhoods with excellent public transportation access, as necessitated by our study's design, these participants do not represent all CPS students. Chicago youth do not enjoy universal access to schools or neighborhoods with these qualities. Our study's comparative design, and its attempt to hold school performance and public transportation access constant, does not amplify the voices of students in Chicago's most racially and socioeconomically isolated schools. We were not able to locate lower-income schools on Chicago's South or West sides whose student performance and public transportation access paralleled Vista's, as Forrester's did. CPS's identification of over 300 schoolspredominantly in racially isolated, low-income neighborhoods - for possible closing the year we recruited school sites further limited our set of potential school sites. These sampling challenges highlight the uneven distribution of educational opportunities across contemporary cities. They also mean that our data do not reflect the entirety of CPS students' experiences with school choice. We contend, however, that the academic performance, socioeconomic, racial, ethnic and 
linguistic diversity present in our student sample did render us able to consider how students across a range of intersectional identities and life circumstances enacted the same policy.

\section{Conclusion}

School choice policy is ubiquitous in U.S. urban districts, shaping millions of young people's educational opportunities. President Donald Trump framed school choice as "the civil rights issue of our time," and promised to expand choice to yet more students (Brown, 2016). Youth voices offer critically valuable perspectives on what an expansion of school choice would portend. In the present study, intradistrict school choice policy influenced participants' academic identities and their subsequent academic behaviors. Student SES moderated this impact, further underscoring the importance of policies' attunement to populations ostensibly served.

This study makes novel contributions by highlighting both the developmental implications of school choice policy, and the specific trajectories that underpin connections between student social status and school choice outcome disparities. It engages these perspectives as windows into youth experience of education policy. Further, it amplifies the voices of youth who directly experience school choice in increasingly diverse U.S. cities. As such, this study stands to inform policymaking as school choice policy expands. Our findings strongly suggest that those who make and evaluate education policy would do well to thoroughly consider and respond to students' intersecting developmental capacities, social status, and the context in which the policy is implemented. Further, policymakers can learn about implemented education policy and its effects by consulting students who live it out each day. More attuned, responsive school choice policy will have greater potential to equitably educate young people. 


\section{Table 1.}

\section{Tables}

Participating K-8 school and CPS demographic information, 2013-2014 school year

\begin{tabular}{llll}
\hline & Forrester & Vista & CPS \\
\cline { 2 - 4 } $\begin{array}{l}\text { Free- or reduced-price lunch } \\
\text { eligible }\end{array}$ & $94 \%$ & $22 \%$ & $85 \%$ \\
Largest racial/ethnic groups & Asian (37\%) & White (60\%) & Latino (45\%) \\
& Latino (32\%) & Latino (20\%) & Black (40\%) \\
& Black (24\%) & Black (10\%) & White (9\%) \\
English language-learners & $42 \%$ & $10 \%$ & $16 \%$ \\
\hline
\end{tabular}

Note: Data retrieved from Chicago Public Schools' Find-A-School and School webpages.

Table 2.

Study participants: Demographic and academic information $(N=36)$

\begin{tabular}{lll}
\hline & Forrester & Vista \\
Free- or reduced-price lunch eligible & 16 & 7 \\
African-American and/or African & 3 & 4 \\
Asian/Pacific Islander & 9 & 1 \\
Latinx & 3 & 2 \\
Multi-racial & 1 & 4 \\
White & 2 & 7 \\
Eligible for selective-enrollment high school entrance exam & 14 & 15 \\
\hline
\end{tabular}

Table 3.

Participants' admissions outcomes, by free and reduced-price lunch eligibility and K-8 school.

$\begin{array}{lcccc} & \text { FRPL-eligible } & \text { Not FRPL-eligible } \\ & \text { Forrester } & \text { Vista } & \text { Forrester } & \text { Vista } \\ \text { Total participants } & 16 & 7 & 2 & 11 \\ \text { High-demand, academically selective school }{ }^{1} & 2 & 0 & 1 & 2 \\ \text { Audition-based school (e.g., performing arts) } & 0 & 0 & 1 & 3 \\ \text { School with moderately selective admissions }{ }^{2} & 7 & 1 & 0 & 2 \\ \text { School with lottery-based or nonselective admissions } & 5 & 4 & 0 & 2 \\ \text { Private school } & 0 & 2 & 0 & 2 \\ \text { Participants rejected by all schools on first application } & 2 & 0 & 0 & 0 \\ \text { round, then enrolled in nonselective high school } & & & \\ \text { 1"High-demand, academically selective schools" are 5 schools that received upwards of 8,000 applications (and as } \\ \text { many as 13,000) and had acceptance rates at or below 10\%. } \\ \text { 2 "Moderately selective admissions" schools used admission criteria, e.g. required essay, exam or interview, but } \\ \text { received fewer applications and rejected fewer applicants than high-demand schools did. }\end{array}$




\section{References}

Ali, T. \& Watson, A.V. (2017, June 19). Less than 25 percent of Chicago kids go to "neighborhood high schools." DNAInfo. Retrieved from https://www.dnainfo.com/chicago/20170619/englewood/chicago-public-schoolsneighborhood-high-school-enrollment-attendance-charter/

Allensworth, E. M., Moore, P. T., Sartain, L., \& de la Torre, M. (2017). The educational benefits of attending higher performing schools: Evidence from Chicago high schools. Educational Evaluation and Policy Analysis, 39(2), 175-197.

Author, 2017 (citation blinded).

Author, 2019 (citation blinded).

Bader, M. D., \& Warkentien, S. (2016). The fragmented evolution of racial integration since the civil rights movement. Sociological Science, 3(8), 135-166.

Ball, S. J., Maguire, M., \& Braun, A. (2012). How schools do policy: Policy enactments in secondary schools. New York, NY: Routledge.

Bell, C. A. (2009). All choices created equal? The role of choice sets in the selection of schools. Peabody Journal of Education, 84(2), 191-208.

Berube, A. \& Holmes, N. (2015). Some cities are still more unequal than others - an update. Washington, D.C.: Brookings Institution. Retrieved from http://www.brookings.edu/research/reports2/2015/03/city-inequality-berube-holmes.

Betts, J. \& Loveless, T. (2005). Getting choice right: Ensuring equity and efficiency in educational policy. Washington, D.C.: Brookings Institution. 
Blakemore, S. J., \& Choudhury, S. (2006). Development of the adolescent brain: implications for executive function and social cognition. Journal of Child Psychology and Psychiatry, 47(3-4), 296-312.

Bourdieu, P. (1984). Distinction: A social critique of the judgment of taste. Cambridge, MA: Harvard University Press.

Brown L. E., Kanny, A., and Johnson B. (2014). "I Am Who I Am Because of Here!" School settings as a mechanism of change in establishing high-risk adolescents' academic Identities. The Journal of Early Adolescence 34 (2), 178-205.

Brown, E. (2016, Dec. 27). School choice or privatization? Lingo fuels feud as fight takes center stage with Trump. Chicago Tribune. Retrieved from http://www.chicagotribune.com/news/nationworld/politics/ct-donald-trump-education20161227-story.html

Burke, L., Ford, V.W., Lips, D., Marshall, J.A., Richine, J., Sheffield, R. \& Walter, E. (2013). Choosing to succeed. Washington, D.C.: The Heritage Foundation. Retrieved from http://www.heritage.org/research/reports/2013/01/choosing-to-succeed-choosing-tosucceed.

Carolan, B. V., Weiss, C. C., \& Matthews, J. S. (2015). Which middle school model works best? Evidence from the Early Childhood Longitudinal Study. Youth \& Society, 47(5), 591614.

Chicago Public Schools (2011). Admissions policy for magnet, selective enrollment and other options for knowledge schools and programs. Chicago Public Schools Policy Manual. Retrieved from http://policy.cps.k12.il.us/documents/602.2.pdf 
Chicago Public Schools. (2013). 2013-2014 CPS high school guide. Chicago, IL: Chicago Public Schools, Office of Access and Enrollment.

Condliffe, B.F., Boyd, M.L., \& DeLuca, S.M. (2015). Stuck in school: How social context shapes school choice for inner-city students. Teachers College Record, 117, 1-36.

Conner, J., Ebby-Rosin, R.\& Brown, A. (2015). Introduction to student voice in American education policy. Teachers College Record, 117(13), 1-18.

Cordes, S. A. (2017). In pursuit of the common good: The spillover effects of charter schools on public school students in New York City. Education Finance and Policy. https://doi.org/10.1162/edfp_a_00240

Cox, T. (2014). Payton College Prep toughest CPS selective-enrollment school to test into. DNAinfo. Retrieved from http://www.dnainfo.com/chicago/20140225/downtown/paytoncollege-prep-toughest-cps-selective-enrollment-school-get-into

Crocetti, E. (2017). Identity formation in adolescence: The dynamic of forming and consolidating identity commitments. Child Development Perspectives, 11(2), 145-150.

Crocetti, E., Rubini, M., Luyckx, K., \& Meeus, W. (2008). Identity formation in early and middle adolescents from various ethnic groups: From three Dimensions to five statuses. Journal of Youth and Adolescence, 37(8), 983-996.

Cucchiara, M. (2013). “Are we doing damage?” Choosing an urban public school in an era of parental anxiety. Anthropology \& Education Quarterly, 44(1), 75-93.

Cullen, J. B., Jacob, B. A., \& Levitt, S. D. (2005). The impact of school choice on student outcomes: an analysis of the Chicago Public Schools. Journal of Public Economics, 89(56), 729-760. 
DeAngelis, C. A., \& Erickson, H. H. (2018). What leads to successful school choice programs: A review of the theories and evidence. Cato Journal, 38(1), 247-263. Retrieved from https://www.cato.org/cato-journal/winter-2018/what-leads-successful-school-choiceprograms-review-theories-evidence\#ch13_ref7.

Eccles, J. S., \& Midgley, C. (1989). Stage-environment fit: Developmentally appropriate classrooms for young adolescents. Research on Motivation in Education, 3, 139-186.

Eccles, J. S., Midgley, C., Wigfield, A., Buchanan, C. M., Reuman, D., Flanagan, C., \& Mac Iver, D. (1993). Development during adolescence: The impact of stage-environment fit on young adolescents' experiences in schools and in families. American Psychologist, $48(2), 90-101$.

Eccles, J.S., Roeser, R. (2015). School and community influences on human development. In M.H. Bornstein and M.E. Lamb (Eds.), Developmental science: An advanced textbook ( $7^{\text {th }}$ Ed.) (645-728). New York, NY: Taylor \& Francis.

Emerson, R.M., Fretz, R.I., \& Shaw, L.L. (2011). Writing ethnographic fieldnotes. Chicago, IL: University of Chicago Press.

Gold, E., Evans, S. A., Haxton, C., Maluk, H., Mitchell, C., Simon, E., et al. (2010). Transition to high school: School "choice" and freshman year in Philadelphia. Philadelphia, PA: Research for Action. Retrieved from http://www.researchforaction.org/wpcontent/uploads/publicationphotos/110/Gold_E_Transition_to_High_School_School.pdf.

Hastings, J. S., Neilson, C. A., \& Zimmerman, S. D. (2012). The effect of school choice on intrinsic motivation and academic outcomes (Working paper no. w18324). Cambridge, MA: National Bureau of Economic Research. Retrieved from 
http://justinehastings.com/wp-

content/uploads/2016/12/HastingsNeilsonZimmerman_w18324.pdf.

Henrich, J., Heine, S. J., \& Norenzayan, A. (2010). The weirdest people in the world? Behavioral and Brain Sciences, 33(2-3), 61-83.

Holme, J. J. (2002). Buying homes, buying schools: School choice and the social construction of school quality. Harvard Educational Review, 72(2), 177-206.

Imberman, S.A. (2011). The effect of charter schools on achievement and behavior of public school students. Journal of Public Economics, 95(7-8), 850-863.

Keating, D. P. (2004). Cognitive and brain development. In Lerner, R. M. \& Steinberg, L. (Eds.), Handbook of adolescent psychology, $2^{\text {nd }}$ ed. (45-84). Hoboken, NJ: John Wiley \& Sons.

Kegan, R. (1995). In over our heads: The mental demands of modern life. Cambridge, MA: Harvard University Press.

Kimelberg, S. M. (2014). Beyond test scores: Middle-class mothers, cultural capital, and the evaluation of urban public schools. Sociological Perspectives, 57(2), 208-228.

Lauen, D. L. (2009). To choose or not to choose: High school choice and graduation in Chicago. Educational Evaluation and Policy Analysis, 31(3), 179-199.

Lipman, P. (2011). The new political economy of urban education: Neoliberalism, race and the right to the city. New York, NY: Routledge.

Loury, A. (2017, Aug. 31). Data Points: Black students declining at Chicago's top public high schools and in CPS overall. Chicago, IL: Metropolitan Planning Council. https://www.metroplanning.org/news/8473/Data-Points-Black-students-declining-atChicagos-top-public-high-schools-and-in-CPS-overall 
Lynch, M., \& Cicchetti, D. (1997). Children's relationships with adults and peers: An examination of elementary and junior high school students. Journal of School Psychology, 35(1), 81-99.

Manno, B., Finn, C.E. \& Vanourek, G. (1999). Charter schools serving disadvantaged youth. Education and Urban Society, 31(4), 429-445.

Menefee-Libey, D. (2010). Neoliberal school reform in Chicago? Renaissance 2010, portfolios of schools and diverse providers. In K. Bulkley, J. Henig and H. Levin (eds.), Between Public and Private: Politics, Governance, and the New Portfolio Models for Urban School Reform (55-90). Cambridge, MA: Harvard Education Press.

Merriam, S. B., Johnson-Bailey, J., Lee, M. Y., Kee, Y., Ntseane, G., \& Muhamad, M. (2001). Power and positionality: Negotiating insider/outsider status within and across cultures. International Journal of Lifelong Education, 20(5), 405-416.

Midgley, C., \& Feldlaufer, H. (1987). Students' and teachers' decision-making fit before and after the transition to junior high school. The Journal of Early Adolescence, 7(2), 225241.

Nasir, N.S., \& Saxe, G. (2003). Ethnic and Academic Identities: A Cultural Practice Perspective on Emerging Tensions and Their Management in the Lives of Minority Students. Educational Researcher 32(5), 14-18.

Nathanson, L., Corcoran, S., \& Baker-Smith, C. (2013). High school choice in New York City: A report on the school choices and placements of low-achieving students. New York, NY: Research Alliance for New York City Schools. Retrieved from https://files.eric.ed.gov/fulltext/ED541824.pdf 
Oyserman, D., Destin, M., \&Novin, S. (2015). "The context-sensitive future self: Possible selves motivate in context, not otherwise." Self and Identity, 14(2), 173-188.

Pattillo, M., Delale-O’Connor, L., \& Butts, F. (2014). High-stakes choosing. In A. Lareau \& K. A. Goyette (Eds.), Choosing homes, choosing schools (237-267). New York: Sage.

Paus, T. (2005). Mapping brain maturation and cognitive development during adolescence. Trends in Cognitive Sciences, 9(2), 60-68.

Piaget, J., \& Inhelder, B. (1973). Memory and intelligence. London, UK: Routledge.

Pillow, W. (2003). Confession, catharsis, or cure? Rethinking the uses of reflexivity as methodological power in qualitative research. International journal of Qualitative studies in education, 16(2), 175-196.

Roda, A. (2015). Inequality in gifted and talented programs: Parental choices about status, school opportunity, and second-generation segregation. New York, NY: PalgraveMacmillan.

Roeser, R. W., \& Lau, S. (2002). On academic identity formation in middle school settings during early adolescence. In T. Brinthaupt and R. Lipka (Eds.), Understanding early adolescent self and identity: Applications and interventions (91-131). Albany, NY: SUNY Press.

Ryan, R., \& Deci E. "Self-determination theory and the facilitation of intrinsic motivation, social development, and well-being." American Psychologist 55(1), 68-78.

Saldaña, J. (2013). The coding manual for qualitative researchers (2nd ed.). Thousand Oaks, CA: Sage. 
Salmela-Aro, K., Kiuru, N., \& Nurmi, J. E. (2008). The role of educational track in adolescents' school burnout: A longitudinal study. British Journal of Educational Psychology, 78(4), 663-689.

Sattin-Bajaj, C. (2014). Unaccompanied minors: Immigrant youth, school choice and the pursuit of equity. Cambridge, MA: Harvard Education Press.

Sattin-Bajaj, C., Jennings, J., Hailey, C., Baker-Smith, C., Cohodes, S., \& Corcoran, S. (2016). "I can't choose for them": How school-level actors respond to the demands of high school choice. Paper presented at the American Educational Research Association Annual Conference, Washington, D.C.

Sattin-Bajaj, C., \& Roda, A. (2018). Opportunity hoarding in school choice contexts: The role of policy design in promoting middle-class parents' exclusionary behaviors. Educational Policy. DOI: 10.1177/0895904818802106.

Segrin, C., Givertz, M., Swaitkowski, P., \& Montgomery, N. (2015). Overparenting is associated with child problems and a critical family environment. Journal of Child and Family Studies, 24(2), 470-479.

Sharkey, P. (2013). Stuck in place: Urban neighborhoods and the end of progress toward racial equality. University of Chicago Press.

Steinberg, L. (2014). Age of opportunity: Lessons from the new science of adolescence. New York, NY: Houghton Mifflin Harcourt.

Stevens, W. D., de La Torre, M., \& Johnson, D. W. (2011). High school choice: Processes and outcomes in Chicago. In M. Berends, M. Cannata \& E. Goldring (Eds.), School choice and school improvement (pp. 124-146). Cambridge, MA: Harvard Education Press. 
Tatum, B. (2017). "Why are all the Black kids sitting together in the cafeteria?": And other conversations about race. New York, NY: Basic Books.

Taylor, K. (2018, March 7). Elite schools make few offers to Black and Latino students. New York Times. Retrieved from https://www.nytimes.com/2018/03/07/nyregion/admissionsspecialized-high-schools-new-york.html

Van Petegem, S., Beyers, W., Vansteenkiste, M. \& Soenens, B. (2012). On the association between adolescent autonomy and psychosocial functioning: Examining decisional independence from a self-determination theory perspective. Developmental Psychology, $48(1), 76-88$.

Yin, R.K. (2013). Case study research: Design and methods (5th ed.). Thousand Oaks, CA: Sage 